\title{
UCZELNIE WYŻSZE A IDEA USTAWICZNOŚCI KSZTAŁCENIA
}

\author{
AleKsandra MarcinKIEWICZ \\ al.marcinkiewicz@gmail.com
}

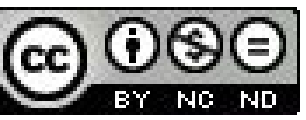

Społeczeństwo przełomu wieku XX i XXI często w literaturze przedmiotu określane jest mianem społeczeństwa informacyjnego, czy też wiedzy. Przyczyn powstania nowego typu społeczeństwa upatruje się w rewolucji informatycznej, czyli w postępie technicznym i informacyjnym. W erze społeczeństwa wiedzy ludzie mają do czynienia z wolnym i nieograniczonym przepływem informacji. Poszukiwanym towarem stały się produkty i usługi informatyczne ${ }^{1}$. Należy zaznaczyć, że cywilizacja w XXI wieku nie będzie, jak do tej pory cywilizacją materialna, lecz niewidoczną․ Człowiek w tych czasach jest jednostką poszukującą swojego szczęścia poprzez wiedzę, a uczenie się jest nieodzownym elementem życia człowieka ery informatycznej.

Jednym z filarów społeczeństwa informacyjnego jest wspomniana już wiedza. W obecnej rzeczywistości nie do przyjęcia jest pogląd, że można w pewnym momencie życia zakończyć swoją edukację. Dynamika zmian we współczesnym świecie powoduje, że wiedza szybko się dezaktualizuje, co wymusza na ludziach bezustanne uzupełnianie posiadanych wiadomości. W społeczeństwie opartym na wiedzy edukacja staje się strategicznym czynnikiem rozwoju społecznego, a urzeczywistnienie tego celu upatruje się w edukacji ustawicznej.

Nowa rzeczywistość edukacyjna przesycona jest ideą w której uznaje się, że proces uczenia rozciagnięty jest na całe życie ${ }^{4}$. Idea ta jest podstawą tworzącego się społeczeństwa informacyjnego. Sama myśl nie jest nowa, gdyż w 1926 r. Eduard Lindeman w dziele Znaczenie edukacji dorosłych opracował tezy, które głosiły, że edukacja nie powinna mieć końca, ponieważ całe życie jest nieustannym procesem uczenia się. . Jednak kształcenie całożyciowe bywa rożnie pojmowane, w zależności od środowiska.

Początkowo za kształcenie ustawiczne uważano doskonalenie ludzi aktywnych zawodowo. Rozwinięciem tego stanowiska było ujęcie, że wszystkie dziedziny oświaty dorosłych składają się na ideę kształcenia ustawicznego, co wyraźnie oddzieliło koncepcję kształcenia ustawicznego od szkolnictwa młodzieżowego, jak i wychowania w rodzinie i środowisku'

Inna koncepcja kładła nacisk na drożność systemu szkolnego. Za system edukacji ustawicznej uważano kształcenie dalsze, a mianowicie szkolnictwo zawodowe, wyższe oraz studia podyplomowe ${ }^{7}$.

Najpełniejszy zakres pojęcia edukacji ustawicznej został przyjęty przez UNESCO, według którego istota kształcenia ustawicznego obejmuje całe życie człowieka i służy jego rozwojowi. Jest to

\footnotetext{
1 M. Dzięgielewska, Człowiek dorosty w społeczeństwie informatycznym, [w:] E. A. Wesołowska (red.), Edukacja dorostych w erze globalizmu, Płock 2002, s. 55.

2 Tamże.

3 E. Dubas, Dorostość w erze informatycznej a zadania edukacji (dorosłych), [w:] E. A. Wesołowska (red.), Edukacja dorostych w erze globalizmu, Płock 2002, s. 150-151.

4 J. Field, Lifelong learning and the new educational order, "Stock on Trent" 2006, s. 9.

5 D. Ciechanowska, Od edukacji ustawicznej do całożyciowego uczenia się - potrzeba kształcenia kompetencji uczynienia się, [w:] R. Górska, J. Półturzycki (red.), Edukacja ustawiczna w szkołach wyższych - od idei do praktyki, Płock-Toruń 2004, s. 155.

6 J. Półturzycki, Szkolnictwo wyższe a idea edukacji ustawicznej, [w:] R. Górska, J. Półturzycki (red.), Edukacja ustawiczna w szkołach wyższych..., dz. cyt., s. 36.

7 Tamże.
} 
również naczelna zasada wskazująca kierunek współczesnych reform szkolnictwa powszechnego, zawodowego i wyższego, ale również doskonalenia zawodowego, oświaty dorosłych, kształcenia równoległego oraz wychowania w rodzinie i środowisku. Głównego zadania edukacji ustawicznej upatruje się $\mathrm{w}$ wychowaniu nowego typu człowieka charakteryzującego się twórczą postawą i dynamicznym stosunkiem do życia i kultury - potrafiącego doskonalić siebie, zmieniać warunki życia i je ulepszać8. Takie rozumienie kształcenia ustawicznego jest uznawane przez naukowców polskich, skandynawskich, francuskich i amerykańskich, choć zdarzają się jeszcze próby utożsamiania edukacji ustawicznej z doskonaleniem zawodowym lub oświatą dorosłych.

Podstawową zasadą kształcenia ustawicznego jest zachowanie ciagłości i systematyczności procesu uczenia się, co zapewnić ma stały rozwój, chroniącjednocześnie przed dezaktualizacją posiadanej wiedzy. Edukacja i rozwój każdej jednostki powinny przebiegać wielopłaszczyznowo, nie tylko w systemie kształcenia szkolnego i wyższego, ale również w systemie oświaty dorosłych i samokształcenia. Zatem, kształcenie ustawiczne obejmuje cały system szkolny oraz oświatę równoległa, kształcenie dorosłych i wychowanie w środowisku. Koncepcja ta w znaczący sposób wpłynęła na przeobrażenia w systemie oświaty wprowadzając nowe cele, formy oraz metody i treści edukacjị.

Podejmując rozważania nad kształceniem ustawicznym należy przywołać pokrewne pojęcie - edukacja permanentna. Pojęcie to zostało wprowadzone przez Radę Europy i jest definiowane jako „system elastycznych form uczenia się; kształcenie ogólne, zawodowe, kulturalne, socjalne i obywatelskie; stałe edukacyjne poradnictwo; wspieranie rozwoju krytycznych i twórczych zdolności; samokształcenie przy zastosowaniu nowoczesnych technik komunikacyjnych"10. Jej funkcje dotyczą głównie odświeżania i aktualizowania wiedzy, co pozwala człowiekowi rozwijać się i nadążać za zmianami ${ }^{11}$.

Mieczysław Malewski ${ }^{12}$ zwrócił uwagę na panujący w andragogice „bałagan pojęciowy". Edukacja permanentna często utożsamiana jest z kształceniem ustawicznym. Jednak wbrew panującej opinii należy oddzielić obie definicje. Jak podaje Daniel Korzan „,kształcenie ustawiczne jest ideą zakładającą kształcenie i wychowanie człowieka przez całe życie. W innym ujęciu jest to potrzeba i cecha charakteryzująca współczesnego człowieka, warunkująca rozwój jego zdolności, śledząca zmiany w społeczeństwie i świecie, a także wszechstronny rozwój osobowości w ciagu całego życia. Przyjmuje się także, że edukacja permanentna oznacza kształcenie, którego celem jest podtrzymanie lub ciagłe rozwijanie wiedzy i umiejętności zawodowych"13. Józef Kargul także zwraca uwagę na problem „zgiełku pojęciowego” w terminologii andragogicznej i błędnego utożsamiania ze sobą pojęć: całożyciowe uczenie się z edukacją permanentną i kształceniem ustawicznym. Przyczyny owego chaosu pojęciowego upatruje on między innymi w niedokładnym przekładzie tekstów obcojęzycznych na język polski ${ }^{14}$. Jednak powód ten nie

8 Tamże.

9 J. Półturzycki, Źródła i tendencje rozwojowe edukacji ustawicznej, http://www.e-mentor.edu.pl/artykul_v2.php?numer=7\&id=97, wydanie internetowe czasopisma , E- mentor" 2004, nr 5, 10.05.2010.

10 A. C. Tuijnman (red.), International Encyklopedia of Adult Education and Training, London-New York-Tokyo, 1996, s. 28, [cyt. za]: K. Mikołajczyk, Kształcenie ustawiczne - od koncepcji do praktyki, www.cren.pl/CREN-SGH_15_KU_2007.pfd, 09.05.2010.

$11 \quad$ K. Mikołajczyk, Kształcenie ustawiczne..., dz. cyt.

12 M. Malewski, Edukacja dorostych w pojęciowym zgiełku. Próba rekonstrukcji zmieniającej się racjonalności andragogiki, „Teraźniejszość - Człowiek - Edukacja” 2001, nr 2, s. 29-30.

13 D. Korzan, W poszukiwaniu istoty edukacji permanentnej, http://www.e-mentor.edu.pl/artykul_v2.php?numer=9\&id=146, wydanie internetowe czasopisma „E- mentor" 2005, nr 2, 10.05.2010.

14 J. Kargul, Obszary pozaformalnej i nieformalnej edukacji dorostych. Przesłanki do budowania teorii edukacji całożyciowej, Wrocław 2001, s. 38- 40 
jest wystarczający, w literaturze anglojęzycznej również można zauważyć nieścisłości terminologiczne w obrębie kształcenia ustawicznego ${ }^{15}$. Robert Kidd ${ }^{16}$ zwracał uwagę na fakt, że idea kształcenia ustawicznego już od wieków widoczna była w poglądach wielu znanych humanistów, jednak dopiero w dzisiejszych czasach stała się ona szczególnie interesująca. Zauważa się również jej możliwości i potrzebę urzeczywistnienia w praktyce edukacyjnej. Urzeczywistnienie kształcenia ustawicznego powinno zintegrować wszystkie formy wychowania i działalności oświatowej, łagodzić różnice pomiędzy kształceniem ogólnym i zawodowym, jak i zapewniać właściwe wykorzystanie czasu wolnego. R. Kidd wyróżnił trzy wymiary kształcenia ustawicznego, do których należy:

- $\quad$ kształcenie w pionie, które obejmuje kolejne szczeble edukacji szkolnej, a więc od przedszkola, poprzez szkołę, do studiów wyższych i podyplomowych. Zasady drożności i dostępności gwarantują młodzieży i dorosłym spełnienie się w tym wymiarze, niezależnie od ich wieku, wykonywanego zawodu, miejsca zamieszkania i innych czynników, które utrudniają edukację.

- $\quad$ kształcenie w poziomie zapewnia poznawanie rozmaitych dziedzin życia, nauki i kultury, niezależnie od studiów pionowych. Likwidacja sztucznych barier pomiędzy dziedzinami życia i kultury umożliwia pełne wykorzystanie tego wymiaru dzięki indywidualnej aktywności jednostki i dzięki działalności pozaszkolnych instytucji oświatowych.

- kształcenie wgłąb ściśle powiązane jest z jakością edukacji i wyraża się w bogatej motywacji kształcenia, $\mathrm{w}$ umiejętnościach samokształceniowych, zainteresowaniach intelektualnych, w stylu życia, który jest zgodny z koncepcją kształcenia ustawicznego, jak i kulturalnym wykorzystaniem czasu wolnego.

Koncepcja ta poszerza rozumienie kształcenia ustawicznego poprzez akcentowanie jakości działań oświatowych i wskazanie bogatych potrzeb, jak i możliwości oświaty pozaszkolnej i oświaty dorosłych. Teoria R. Kidda ma istotne znaczenie dla edukacji dorosłych, ponieważ łączy trzy formy aktywności edukacyjnej: kształcenie szkolne, oświatę pozaszkolną i samokształcenie. Nie ujmuje ich zastępczo lub przeciwstawnie, ale kładzie nacisk na konieczność łącznego urzeczywistniania aktywności edukacyjnej, w trzech wyżej wspomnianych wymiarach kształcenia. Implikuje zatem edukację programowaną w szkołach i uczelniach, wspieraną aktywnością samokształceniową i udziałem $\mathrm{w}$ formach pozaszkolnej oświaty dorosłych ${ }^{17}$.

Edukacja we współczesnym świecie stała się integralną częścią życia, pozwalającą na łatwiejsze funkcjonowanie w otaczającej nas rzeczywistości. Obecnie można również spotkać się z opiniami, że całożyciowe uczenie się nie jest już dobrowolną aktywnością edukacyjną podejmowaną przez uprzywilejowaną część społeczeństwa, ale wręcz przymusem i koniecznościa, niezbędną do właściwego funkcjonowania $\mathrm{w}$ otaczającym świecie ${ }^{18}$. Z tego względu edukacja dorosłych zajmuje ważne miejsce w koncepcji kształcenia ustawicznego. Każdy proces edukacyjny, w tym odnoszący się do ludzi dorosłych musi składać się z trzech komponentów: uczeń, nauczyciel i wiedza. Jednym z istotniejszych elementów wyróżniających edukację dorosłych jest fakt, że ludzie ci posiadają już indywidualne doświadczenia, które są ważnym czynnikiem w procesie edukacyjnym. Ponadto proces edukacyjny jest podejmowany przez nich dobrowolnie i świadomie, czego nie można powiedzieć w przypadku dzieci objętych obowiązkiem szkolnym.

15 J. Field, Lifelong learning and the new educational order, Stock on Trent 2006, s. 2-3.

16 J. Półturzycki, Szkolnictwo wyższe a idea...,dz. cyt., s. 38.

J. Półturzycki, Akademicka edukacja dorostych, Warszawa 1994, s. 30-31.

M. Malewski, Edukacja dorostych w pojęciowym zgietku..., dz. cyt., s. 37. 
M. Malewski ${ }^{19}$ wyszczególnił trzy modele pracy edukacyjnej z ludźmi dorosłymi, do których należą:

- model technologiczny - $\mathrm{w}$ tym modelu $\mathrm{w}$ centrum procesu edukacyjnego postawiony jest nauczyciel. Nauczyciel jest osoba, która w sposób dyrektywny przekazuje wiedzę dorosłym uczniom, wyposaża ich w obiektywny obraz świata oraz wzorce skutecznego w nim działania. $W$ omawianym modelu edukacja jest traktowana w sposób instrumentalny w stosunku do potrzeb społecznych. Również w taki sposób potraktowany jest nauczyciel, gdyż to tylko na nim spoczywa odpowiedzialność za wyniki kształcenia. Natomiast uczeń sprowadzony jest do postaci biernego odbiorcy treści przekazywanych przez nauczyciela.

- model humanistyczny - zakłada partnerską relację pomiędzy nauczycielem i uczniem, a więc mamy do czynienia ze współpracą nauczyciela z uczniem, gdyż to on jest centralnym elementem procesu edukacyjnego. Konsekwencją tej relacji jest fakt, że program i treści nauczania odnoszą się do potrzeb ucznia. Edukacja ma w rozumieniu tego modelu służyć wielostronnemu rozwojowi ucznia.

- model krytyczny - całkowita samodzielność ucznia powoduje w tym modelu zatarcie oficjalnych programów i treści nauczania. Aktywność edukacyjna ma przyczynić się do pogłębienia swoich kompetencji i zainteresowań pozwalających uzyskać szerszą perspektywę świata. W modelu tym ważna jest refleksyjność, krytyczne myślenie ucznia i zdobywanej wiedzy, jak otaczającej rzeczywistości. Nie istnieje w tym modelu nauczyciel w tradycyjnym rozumieniu tego słowa, gdyż tę rolę mogą pełnić różnego rodzaju media. Można posunąć się do stwierdzenia, że uczeń chłonie wiedzę z „życia codziennego": z filmów, programów telewizyjnych, literatury itp.

Pomocna $w$ porządkowaniu myślenia o edukacji ustawicznej jest typologia opracowana przez P. H. Coombsa, który wyróżnił trzy jakościowo odmienne subobszary: edukację formalna, pozaformalną i nieformalną $a^{20}$. Za kształcenie formalne uznaje się hierarchiczny system instytucji oświatowych, który poprzez świadectwa, certyfikaty i dyplomy szkolne selekcjonuje uczniów do różnych ról społecznych i umiejscawia ich na różnych poziomach struktury społecznej. Edukacja pozaformalna, to te aktywności edukacyjne, sytuujące się poza formalnym systemem oświaty, do których należą m.in. kursy, seminaria, odczyty, koła miłośników, dokształcanie w różnej postaci, studia podyplomowe itp. Natomiast za edukację nieformalną uznaje się procesy edukacyjne, w których osoba ucząca się przyswaja wiedzę, postawy, wartości, umiejętności z powszechnego doświadczenia, jak i zasobów i wpływów środowiska ${ }^{21}$.

Jak zwraca uwagę J. Kargul w ostatnim czasie nastąiłło w edukacji dorosłych przeniesienie akcentu z kształcenia formalnego, dominującego w XX wieku w kształceniu ustawicznym, na rzecz edukacji nieformalnej i pozaformalnej, $\mathrm{w}$ których to dorosły uczący się łatwiej rozwija określone kompetencje pozwalające mu rozwiązywać życiowe problemy ${ }^{22}$. Takie stanowisko wydaje się być zbliżone do teorii przestrzeni uczenia się Knuda Illerisa ${ }^{23}$. Wyodrębnił on sytuacje (przestrzenie), w których zachodzi uczenie się, a mianowicie: z codzienności, poprzez praktykę albo

\footnotetext{
19 M. Malewski, Modele pracy edukacyjnej z ludźmi dorostymi, „Teraźniejszość - Człowiek - Edukacja” 2000, nr 1 (9), s. 47-63.

20 Tamże, s. 57

21 Tamże.

J. Kargul, Obszary pozaformalnej i nieformalnej..., dz. cyt., s. 40.

K. Illeris, Trzy wymiary uczenia się, Wrocław 2006, s. 187-216.
} 
praktykowanie, czy w szkołach i innych instytucjach edukacyjnych oraz w miejscu pracy. Uczenie się oraz jego rezultaty $\mathrm{w}$ instytucjach zorganizowanej edukacji zawszę będą znacznie różniły się od realiów i wymagań świata zewnętrznego. Wiedza zdobyta w instytucji (szkole) umożliwia właściwe funkcjonowanie w środowisku szkolnym, natomiast poza nim jest prawie bezużyteczna. Z tego powodu istnieje rozbieżność między edukacją a rzeczywistością społeczną. Nie można zaprzeczyć, że instytucje nie są jedyną przestrzenia, w której dochodzi do sytuacji uczenia się. Co więcej inne przestrzenie - uczenie się z codzienności, uczenie się praktyczne i praktykowanie, czy uczenie się w pracy - dają więcej możliwości do uczenia się tego właśnie, co jednostce jest niezbędne do życia, a więc bardziej praktyczne. Jak można zauważyć przestrzenie te wyraźnie korespondują ze wspomnianymi modelami kształcenia podkreślając duże znaczenie kształcenia nieformalnego i pozaformalnego. $\mathrm{W}$ związku z powyższym nie jest zaskakujące, że w ostatnim czasie w kształceniu ustawicznym kładzie się nacisk na te właśnie modele kształcenia.

Zestawiając ze sobą wszystkie powyższe teorie można zauważyć pewne zależności. Wyraźnie widać, że przestrzenie poszczególnych teorii korespondują ze sobą tworząc wspólne obszary, charakterystyczne dla konkretnej formy uczenia się. Należy jednak zaznaczyć, że zestawione koncepcje nie są ze sobą tożsame, a jedynie posiadają elementy wspólne, dzięki którym można je zaliczyć do jednej grupy.

Tabela 1. Wymiary kształcenia ustawicznego, modele pracy z ludźmi dorosłymi, subobszary kształcenia i przestrzenie uczenia się - obszary wspólne.

\begin{tabular}{|c|c|c|c|}
\hline $\begin{array}{c}\text { R. Kidd- } \\
\text { wymiary kształcenia } \\
\text { ustawicznego }\end{array}$ & $\begin{array}{c}\text { M. Malewski -modele pra- } \\
\text { cy z ludźmi dorosłymi }\end{array}$ & $\begin{array}{c}\text { P. H. Coombs- } \\
\text { subobszary kształcenia }\end{array}$ & $\begin{array}{c}\text { K. Illeris- } \\
\text { przestrzenie uczenia się }\end{array}$ \\
\hline Kształcenie w pionie & Model technologiczny & Kształcenie formalne & $\begin{array}{c}\text { Uczenie się w szkole } \\
\text { i innych instytucjach } \\
\text { edukacyjnych }\end{array}$ \\
\hline Kształcenie w poziomie & Model humanistyczny & Kształcenie pozaformalna & $\begin{array}{c}\text { Uczenie się w miejscu } \\
\text { pracy; uczenie się poprzez } \\
\text { praktykę/ praktykowanie }\end{array}$ \\
\hline Kształcenie wgłąb & Model krytyczny & Kształcenie nieformalne & \begin{tabular}{c} 
Uczenie się z codzienności \\
\hline
\end{tabular} \\
\hline
\end{tabular}

Źródło: opracowanie własne.

Zależność poszczególnych teorii będzie lepiej widoczna, gdy posłużymy się przykładem. Rozpatrując przykładowo miejsce studiów wyższych w poszczególnych teoriach można zauważyć, że ta forma kształcenia umiejscowiona jest kolejno w pionowym obszarze kształcenia, jak i w kształceniu formalnym. Dodatkowo jest to przestrzeń uczenia się w szkole i innych instytucjach edukacyjnych, a przypisanym modelem pracy z ludźmi dorosłymi jest model technologiczny. Zatem rozpatrując przykład studiów wyższych zarysował się wspólny dla wszystkich koncepcji obszar. Podobna zależność widoczna jest w pozostałych dwóch obszarach. Kursy i szkolenia różnego rodzaju są przykładem uczenia się poprzez praktykę/praktykowanie. Umiejscowione są w kształceniu poziomym, są także formą edukacji pozaformalnej, a przypisanym im modelem pracy z ludźmi dorosłymi jest model humanistyczny. Ostatni przypadek dotyczy 
uczenie się z codzienności (np. gdy mamy do czynienia z pogłębieniem wiedzy z kręgu zainteresowań), któremu odpowiada model krytyczny. Jest to również wymiar kształcenia wgłąb koncepcji R. Kidda, jak i subobszar kształcenia nieformalnego.

Realizacją kształcenia ustawicznego zajmują się w naszym kraju instytucje podlegające administracji publicznej lub działające na wolnym rynku na mocy prawa gospodarczego. Czynnikami różnicującym wspomniane instytucje są formy, zakres działalności edukacyjnej oraz oferowane stopnie wykształcenia i certyfikaty. W Polsce możemy wyróżnić następujące instytucję

- szkoły wyższe;

- Centra Kształcenia Ustawicznego (CKU);

- Centra Kształcenia Praktycznego (SKP);

- placówki naukowe, ośrodki badawczo - rozwojowe;

- szkoły dla dorosłych;

- ośrodki szkolenia, dokształcania i doskonalenia kadr, stowarzyszenia, fundacje, spółki oraz inne podmioty;

- pracodawcy.

W raporcie Jacquesa Delorsa, przedstawiającym kierunki rozwoju edukacji XXI wieku, ważne miejsce $\mathrm{w}$ kształceniu ustawicznym przypisano uczelniom wyższym. Twórcy tego raportu określają szkolnictwo wyższe „(...) motorem rozwoju gospodarczego, celem edukacji przez całe życie, depozytariuszem i kreatorem wiedzy oraz głównym narzędziem przekazywania doświadczenia kulturowego i naukowego, jakie nagromadziła ludzkość' ${ }^{\prime 25}$. Według raportu uniwersytety nie będą ograniczać się tylko do powszechnego kształcenia ustawicznego, ale również dokształcać zainteresowanych na najwyższym poziomie, odnawiać system kształcenia, wypracowywać i wdrażać w edukację innowacje. W uniwersytetach upatruje się pomostu łączącego szkolnictwo wyższe z dalszą edukacją. Mają one stanowić sieć ośrodków kształcenia ustawicznego oraz centrów służących ochronie kultury, jak i jej wzbogacaniu ${ }^{26}$.

Do połowy minionego stulecia podstawowe funkcje uniwersytetu sprowadzały się do kształcącej i badawczej. W wieku XX mamy do czynienia z umasowieniem uniwersytetów i traktowania ich jak ",hurtowni pojęc", czyli przygotowywania w szybkim czasie do zawodu i dostarczania przede wszystkim wiedzy typu know-how. Oczekuje się od nich, iż będą one pełnić służebną rolę wobec społeczeństwa. Uniwersytety zmuszone są do rywalizacji z szeroką ofertą edukacyjną różnego rodzaju wyższych szkół zawodowych. W związku z tym wprowadzono w uniwersytetach nowe formy organizacyjne, nowe kierunki, wydziały i tryby studiów. Pomimo przeciwności uniwersytety walczą o utrzymanie niezależności badań naukowych i kształcenia, czego przejawem jest oparcie procesu kształcenia na wiedzy ogólnejej.

Istotne zmiany na uniwersytetach $\mathrm{w}$ Wielkiej Brytanii zaczęły pojawiać się $\mathrm{w}$ drugiej połowie XX w. Do tego czasu edukacja uniwersytecka była mocno oddzielona od innych form dalszego kształcenia ludzi dorosłych. W latach 60. pojawia się edukacja dorosłych (edukacja dalsza), która funkcjonuje niezależnie od kształcenia wyższego. Od $1980 \mathrm{r}$. wiele placówek dalszego

24 B. Kędzierska, Kształcenie ustawiczne jako priorytetowa koncepcja wszystkich krajów europejskich, http://www.wsp. krakow.pl/ecemi/file/Kszt_Ust_podstawy.pdf, strona internetowa Uniwersytetu Pedagogicznego im. Komisji Edukacji Narodowej w Krakowie, 20.05.2010.

25 J. Delores (red.), Edukacja - jest w niej ukryty skarb. Raport dla UNESCO Międzynarodowej Komisji do spraw Edukacji dla XXI wieku, Warszawa 1998, s. 135.

26 J. Półturzycki, Szkolnictwo wyższe a idea..., dz. cyt., s. 52

27 A. Kobylarek, Uniwersytet-zarys ezolucji idei podstawowej, „Nauka i Szkolnictwo Wyższe” 2002, nr 1, s. $94-97$. 
kształcenia zaczęło proponować niższy poziom kształcenia zawodowego i zaabsorbowały one zinstytucjonalizowaną edukację dorosłych. W latach 90. XX wieku w Wielkiej Brytanii mamy do czynienia z dwiema kategoriami odnoszącymi się do edukacji dorosłych - edukacja dalsza (poszkolna) i edukacja wyższa, z których w 1997 r. utworzono nową kategorię: Lifelong Learning - kształcenie przez całe życie ${ }^{28}$.

Natomiast przeobrażenia na polskich uniwersytetach pojawiły się pod koniec lat 90. ubiegłego stulecia. Dotyczyły one restrukturyzacji, która stopniowo obejmowała całokształt akademickiego życia, badania naukowe i zarządzanie. Zapoczątkowaniem wspomnianych zmian było podpisanie przez cztery państwa Unii Europejskiej (Wielka Brytania, Niemcy, Włochy i Francja) deklaracji Sorbońskiej, przedstawiającej koncepcje harmonizacji europejskiego szkolnictwa wyższego. Duży potencjał i możliwości tej idei dostrzegły również inne państwa, w tym Polska, gdyż rok później 29 krajów podpisało tzw. Deklarację Bolońska, od której zaczęła się realizacja Procesu Bolońskiego. Sam proces jest bardzo wyjątkowy w skali światowej, gdyż zmierza do harmonizacji, a nie ujednolicenia kształcenia uniwersyteckiego. Takie stanowisko wskazuje, że siłę rozwojową dostrzega się w różnorodności przy jednoczesnym zachowaniu autonomii uczelni. Deklaracja Bolońska wskazuje na ogólne sposoby realizacji wspomnianych celów, do których należąa29:

- wprowadzenie systemu porównywalnych dyplomów;

- wprowadzenie 2 i 3 stopniowych studiów;

- wprowadzanie punktowego systemu rozliczania osiagnięć studentów - ECTS;

- wdrażanie mobilności studentów i pracowników w Europie;

- współdziałanie w celu zagwarantowania jakości kształcenia.

Rozszerzeniem i uszczegółowieniem Deklaracji Bolońskiej był podpisany w 2001 r. Komunikat Paryski, uzupełniający tę listę o postulat kształcenia ustawicznego w uczelniach wyższych oraz o współpracę i współdziałanie uczelni, pracowników i studentów w realizacji Procesu Bolońskiego. Wszystkie wspomniane wyżej dokumenty stanowią całość wytycznych i modernizacji Europejskiego Obszaru Szkolnictwa Wyższego ${ }^{30}$. Na aspekt kształcenia ustawicznego zwracają uwagę również inne akty prawne, jak na przykład Komunikat ze spotkania europejskich ministrów ds. szkolnictwa wyższego pt. Ku europejskiemu obszarowi szkolnictwa wyższego, podpisany w $2001 \mathrm{r}^{31}$

Wprowadzenie idei ustawiczności kształcenia, na uczelniach wyższych, odnosi się do podnoszenia jakości i efektywności poziomu kształcenia, rozszerzenia oferty edukacyjnej wykorzystującej nowe techniki, wspierania rozwoju człowieka i zwiększenia jego udziału w życiu społecznym, zapewnienia dostępu do szkolnictwa wyższego, jak i rozwijania współpracy między samymi uczelniami oraz między uczelniami a środowiskiem lokalnym i światem biznesu ${ }^{32}$. Proces ten implikuje wprowadzenie nowych celów, form, metod i treści kształcenia. W związku z powyższym, uczelnie oprócz tradycyjnej funkcji dydaktycznej realizują całkiem nowe, takie jak realizacja idei ustawiczności i rozwijanie współpracy międzynarodowej, rozwijanie kształcenia specjalistycznego ${ }^{33}$.

\footnotetext{
28 P. Scott, The death of mass higher education and the birth of lifelong learning, [w:] J. Field, M. Leicester (red.), Lifelong Learning. Education Across the Lifespan, Londyn 2000, s. 29.

29 Deklaracja Bolońska i co dalej: zbiór komunikatów, wytycznych i sugestii. Materiały ze strony internetowej MENiS http:// wwww.menis.gov.pl. Konferencja Rektorów Uniwersytetów Polskich, 23.05.2010, s. 2-3.

30 J. Półturzycki, Szkolnictwo wyższe a idea..., dz. cyt., s. 35.

31 Deklaracja Bolońska i co dalej: zbiór komunikatów, wytycznych..., dz. cyt., s. 20.

32 M. Groenwald, Edukacja przez całe życie - od idei do praktycznych rozwiazań, [w:] R. Górka, J. Półturzycki (red.), Edukacja ustawiczna w szkołach wyższych - od idei do praktyki, Płock-Toruń 2004, s. 126.

33 J. Połturzycki, Szkolnictwo wyż̇ze a idea..., dz. cyt., s. 52.
} 
W związku z ideą ustawicznej edukacji model kształcenia uniwersyteckiego rozszerzył się o studia niestacjonarne zbliżone pod względem treści do kierunków stacjonarnych, ewentualnie o studia podyplomowe. Obecnie uczelnie wyższe rozszerzają formy kształcenia również o kursy i szkolenia na poziomie nie tylko uniwersyteckim ${ }^{34}$.

Ciekawą propozycją uczelni jest kształcenie otwarte, nazywane także uniwersytetem otwartym. Forma ta wydaje się być propozycją najpełniej ucieleśniającą ideę ustawiczności kształcenia na poziomie wyższym. Uniwersytety otwarte są przeznaczone dla wszystkich chętnych do podjęcia nauki, bez względu na uzyskane do tej pory wykształcenie i posiadane dyplomy. Rozwiązanie to odpowiada na potrzeby osób, którym warunki życia nie pozwoliły rozpocząć kształcenia lub dokończyć studiów. Forma ta pozwala na uzyskanie dyplomu i tytułu akademickiego, ale nie stanowi to jej najistotniejszego celu. W kształceniu otwartym wykorzystuje się przede wszystkim znane metody kształcenia korespondencyjnego, ale również telewizję, radio, wspomaganie komputerowe, filmy i inne ${ }^{35}$. Oprócz powyższych form uczelnie rozszerzają swoją ofertę edukacyjną poprzez wydawanie materiałów dydaktycznych, instruktażowych i szkoleniowych ${ }^{36}$.

Należy pamiętać, że do 1989 r. kształcenie wyższe miało w Polsce charakter elitarny. Ograniczona liczba uczelni wyższych, mała ilość miejsc i elitarne zasady rekrutacji powodowały, że dostęp do tej formy kształcenia mieli nieliczni. Od 1990 r. szkolnictwo musiało zmierzyć się z realiami świata kapitalistycznego. Uczelnie, które wcześniej funkcjonowały poza rynkiem pracy i rynkiem edukacyjnym musiały sprostać oczekiwaniom studentów (klientów) oraz zapotrzebowaniom rynku pracy $^{37}$. Zaistniała konieczność przystosowania oferty edukacyjnej do nowej rzeczywistości. Dostosowanie programu kształcenia do potrzeb zainteresowanych powinno zawierać następujący cykl działań: poznanie środowiska, zdefiniowanie charakterystyki rynku, ocena możliwości stwarzanych w obrębie rynku i ocena możliwości własnej infrastruktury i priorytetów strategicznych. Wynikiem tych działań powinno być określenie liczby osób zainteresowanych kształceniem, potrzeb edukacyjnych danej grupy, struktury grupy i zdiagnozowanie poszukiwanych obszarów wiedzy. Następnym etapem jest określenie przez uczelnie możliwości dostosowania własnego programu edukacji ustawicznej do otrzymanej charakterystyki, wyrażonej $w$ formie listy potrzeb dotyczących: kadry, środków technicznych i niezbędnych inwestycji. Niestety struktura szkół wyższych w Polsce nie przewiduje monitorowana sytuacji gospodarczej i rynku pracy ${ }^{38}$.

Komisja Europejska jest inicjatorem wielu interesujących programów dotyczących edukacji o czym świadczy projekt Sokrates. I faza wspomnianego programu realizowana była w latach 19951999, natomiast II faza w latach 2000-2006. Składał się on z kilku komponentów obejmujących rozmaite obszary i poziomy edukacji. Uczenie się dorosłych, $\mathrm{w}$ tym kształcenie ustawiczne, objęte są programem Grundtviga ${ }^{39}$, który do roku 2006/07 funkcjonował jako część programu Sokrates II 20002006. Od 2007 r. realizowany jest program o nazwie Uczenie się przez całe życie, składający się z czterech filarów, do których należy Gruntvig ${ }^{40}$. Program ma za zadanie osiągnięcie następujących celów:

34 Z. Wiśniewski, Rola uczelni w kształceniu ustawicznym w społeczeństwie na przykładzie potrzeb edukacyjnych osób pozyżej 50 roku życia, http://www.e-mentor.edu.pl/artykul_v2.php?numer=26\&id=568, internetowe wydanie czasopisma „E- mentor" 2008, nr 4, 20.05.2010.

35 J. Półturzycki, Szkolnictwo wyższe a idea..., dz. cyt., s. 40.

36 Z. Wołk, Wstęp, [w:] Z. Wołk (red.), Szkolnictwo wyższe w systemie kształcenia ustawicznego, Zielona Góra 2009, s. 5.

37 E. Kurantowicz, O uczacych się społecznościach. Wybrane praktyki edukacyjne ludzi dorosłych, Wrocław 2007, s. 112-113.

38 Z. Wiśniewski, Rola uczelni w kształceniu ustawicznym..., dz. cyt.

39 E. Marciszewska, A. Zbierzchowska, Kształcenie ustawiczne na uniwersytetach. Projekty EQUIPE i EQUIPE PLUS, http://www.e-mentor.edu.pl/artykul_v2.php?numer=16\&id=334, internetowe wydanie czasopisma „E-mentor” 2006, nr 4, 23.05.2010.

40 Strona internetowa programu Grundtvig, http://grundtvig.org.pl/index.php/ida/2/, 23.05.2010. 
- poprawa jakości edukacji dorosłych poprzez szeroką wymianę doświadczeń, praktyk, metod kształcenia oraz dzięki podnoszeniu kwalifikacji kadry placówek edukacji dorosłych;

- opracowanie wysokiej jakości oferty dydaktycznej, w których będzie wykorzystywana nowa technologia;

- rozszerzenie współpracy pomiędzy instytucjami kształcącymi dorosłych w całej Europie;

- zagwarantowanie szerokiego dostępu do różnych form kształcenia dorosłych;

- promowanie innowacyjnych metod w kształceniu dorosłych;

- $\quad$ promowanie i popularyzacja idei uczenia się przez całe życie - kształcenia ustawicznego ${ }^{41}$.

W Polsce Rada Ministrów przyjęła w 2003 r. dokument zatytułowany Strategia rozwoju ksztatcenia ustawicznego do roku 2010, zawierający kierunki rozwoju kształcenia ustawicznego w Polsce, zgodne ze Strategią Lizbońską. Z pewnością Strategia jest dokumentem istotnym, gdyż podkreśla rolę edukacji ustawicznej. Należy jednak zwrócić uwagę, że dokument ten jest niekompletny i nie w pełni dopracowany, co zauważył Józef Półturzycki dokonując jego analizy w jednym ze swoich artykułów. Fakt, że w Strategii użyto nieaktualnej definicji kształcenia ustawicznego świadczy o ignorancji twórców dokumentu wobec podstawowych prac i raportów naukowych dotyczących kształcenia ustawicznego. Ponadto, utożsamia się kształcenie ustawiczne z doskonaleniem zawodowym i edukacją dorosłych, przez co odcina się od edukacji ustawicznej szkolnictwo podstawowe, średnie i wyższe. Dużym uchybieniem jest również pominięcie roli nauczycieli $\mathrm{w}$ procesie przygotowującym do całożyciowego uczenia się. J. Półturzycki zwraca uwagę, że nie szkoły dla dorosłych, jak to ujęto w Strategii będą ośrodkami edukacji ustawicznej, ale właśnie pominięte $\mathrm{w}$ dokumencie uniwersytety ${ }^{42}$.

Niezaprzeczalnie, kształcenie ustawiczne jest integralną częścią działalności uczelni wyższych. W związku z tym, wybór odpowiedniego systemu zarządzania kształceniem ustawicznym zasadniczo wpływa na jakość kształcenia tej instytucji. System zarządzania kształceniem ustawicznym na polskich uniwersytetach jest odmienny od obowiązującego w większości krajów europejskich. Zbigniew Wiśniewski w artykule pt. Ksztatcenie ustawiczne - centralne czy niezależ$n e^{43}$ porównał organizacje i zarządzanie uniwersyteckim kształceniem ustawicznym w Polsce ze stosowanym na uczelniach innych krajów Unii, a następnie dokonał analizy skuteczności obu systemów. W Polsce przeważa system oparty na niezależnym działaniu wydziałów uczelni. Takie usytuowanie systemu kształcenia ustawicznego jest wynikiem niezależnego działania katedr i wydziałów. Schemat zarządzania kształceniem ustawicznym na wydziale uczelni obejmuje:

- prodziekana ds. studiów zaocznych i wieczorowych, który zwykle stanowi „ośrodek decyzyjny";

- pracowników dziekanatu, którzy wykonują czynności związane z rejestracja ewidencją postępów studentów, kontrolą wpłat i inne;

- jednego / kilka pracowników dydaktycznych, którzy zajmują się planowaniem miejsca i czasu zajęć;

- pracownika zatrudnionego w kwesturze uczelni, który prowadzi rejestrację wpłat;

- dział kształcenia uczelni, gdzie znajdują się osoby nadzorujące przebieg kształcenia niestacjonarnego na wydziałach, ale również ewidencjonują informacje otrzymane z dziekanatów.

${ }_{41} \quad$ E. Marciszewska, A. Zbierzchowska, Kształcenie ustawiczne..., dz. cyt.

42 J. Półturzycki, Aktualność problemów edukacji ustawicznej, http://www.e-mentor.edu.pl/artykul_v2.php?nume$\mathrm{r}=13 \& \mathrm{id}=244$, internetowe wydanie czasopisma „E-mentor” 2006, nr 1, 23.05.2010.

${ }^{43}$ Z. Wiśniewski, Kształcenie ustawiczne- centralne czy niezależne?, http://www.e-mentor.edu.pl/artykul_v2.php?numer=16\&id=337, internetowe wydanie czasopisma „E- mentor" 2006, nr 4, 23. 05. 2010. 
Przedstawiony powyżej schemat organizacji zarządzania kształceniem ustawicznym implikuje konieczność przeznaczenia większej ilości czasu na skoordynowanie pracy pomiędzy komórkami organizacji. Efektem jest przeciążenie nielicznej kadry administracyjnej obowiązkami związanymi z kształceniem ustawicznym. Niewielka grupa pracowników nie może skoncentrować się na działaniach strategicznych, planowaniu i analizowaniu jakości studiów, ponieważ skupiona jest na bieżących czynnościach, pochłaniających znaczną część ich czasu. W związku z tym zadania te spadają na pracowników dydaktycznych.

W krajach Unii Europejskiej i w wielu polskich niepublicznych uczelniach wyższych kształcenie ustawiczne realizowane jest przez centralne ośrodki, usytuowane w strukturze uczelni, działające niezależnie. Takie rozwiązanie pozwala na lepszą organizację pracy i przeznaczenie większej ilości czasu na działania strategiczne, planowanie i analizę jakości kształcenia, tworzenie bazy technicznej i efektywniejsze dysponowanie środkami finansowymi.

Duży wkład do oceny akademickiego kształcenia ustawicznego wniósł raport z konferencji: Edukacja ustawiczna a szkoty wyższe w XXI wieku ${ }^{44}$, opublikowany w $1998 \mathrm{r}$. W raporcie zwrócono uwagę na zmiany jakie muszą nastąić na uczelniach wyższych, aby stały się one instytucjami uczenia się przez całe życie. Zmiany te dotyczą przede wszystkim:

- bardziej elastycznego podejścia do warunków rekrutacji na studia;

- rozwoju edukacji na odległość;

- metod kształcenia;

- utworzenia systemu, który będzie akceptował doświadczenia zdobyte przez dorosłych w edukacji nieformalnej;

- $\quad$ sposobów przyznawania kredytów edukacyjnych;

- zbliżenia się uniwersytetów do społeczności lokalnej.

Podstawowy wniosek wypływający z raportu jest taki, że instytucje szkolnictwa wyższego powinny zastosować się do powyższych wskazań, jeśli nie chcą zostać zmarginalizowane na rynku edukacyjnym. Zauważalne są poszukiwania rozmaitych możliwości zaspokojenia dążeń osób dorosłych do zdobycia wiedzy. W przypadku, gdy dorośli napotykają przeszkody w postaci zbyt wysokich wymagań rekrutacyjnych na studia, poszukują innych możliwości, które są wolne od takich barier, a wiedza przekazywana jest $w$ bardziej atrakcyjny sposób. Jest to dowód na silny związek kształcenia ustawicznego z ekonomią i rynkiem.

W celu zbadania sposobu i stopnia realizowania ustawiczności kształcenia przez Uniwersytet Wrocławski poddałam analizie stronę internetową uczelni. Przykuwa uwagę fakt, że w strukturze uczelni nie ma jednostki zajmującej się kształceniem ustawicznym. Do form kształcenia ustawicznego proponowanych przez Uniwersytet Wrocławski można z pewnością zaliczyć szeroką ofertę studiów podyplomowych oraz działający przy uczelni Uniwersytet Trzeciego Wieku, formułę otwartych wykładów, działalność kół naukowych, konferencje i odczyty, czy działalność uczelnianego Biura Karier.

Zwrócenie się uczelni wyższych w stronę potrzeb i oczekiwań osób chcących się rozwijać i kształcić, to jedna z najistotniejszych zmian w zakresie edukacji ustawicznej na poziomie wyższym. Niemniej, uniwersytety starając się wypełniać nową funkcję (kształcenia ustawicznego), nie powinny zagubić funkcji badawczej i kształcącej, które są fundamentalne, gdyż wyznaczają jego istotę. Zgodnie z koncepcją całożyciowego uczenia się dostęp do kształcenia powinien być równy bez względu na posiadane wykształcenie. Jednak ten postulat wydaje się być trudny do

\footnotetext{
44 A. Frąckowiak , Edukacja ustawiczna a szkoły wyższe w XXI wieku, [w:] R. Góralska, J. Półturzycki (red.), Edukacja ustawiczna w szkołach wyższych - od idei do praktyki, Płock-Toruń 2004, s. 263.
} 
zrealizowania w obrębie kształcenia uniwersyteckiego, gdyż większość ofert w zakresie kształcenia ustawicznego, jak studia podyplomowe, czy inne formy aktywności naukowej skierowane są do osób zdobywających lub już posiadających wyższe wykształcenie. Wyjątek na Uniwersytecie Wrocławskim stanowi Uniwersytet Trzeciego Wieku, który umożliwia udział w zajęciach również osobom bez wyższego wykształcenia. Uniwersytety odzwierciedlają idee kształcenia ustawicznego w podnoszeniu jakości i efektywności kształcenia, rozszerzaniu oferty edukacyjnej, w której wykorzystuje się nowe techniki, czy rozwijaniu współpracy między uczelniami oraz między instytucją kształcenia wyższego a środowiskiem lokalnym. Dyskusyjny jest postulat obniżenia wymagań rekrutacyjnych $w$ dostępie do studiów wyższych, ponieważ grozi to znacznym obniżeniem się poziomu kształcenia uniwersyteckiego. Problematyczne jest także, uwzględnianie przy rekrutacji posiadanej przez kandydatów wiedzy nieformalnej i pozaformalnej, gdyż są to obszary, których nie sposób zmierzyć i poddać ocenie. Bez wattpienia wiele korzyści dla akademickiego kształcenia ustawicznego płynie z uczestnictwa uczelni w programach edukacyjnych oferowanych przez Unię Europejską. Uczelnie wyższe stanowią istotny element idei kształcenia ustawicznego, gdyż dysponują potencjałem, którego umiejętne wykorzystanie i pokierowanie przyczyni się do lepszego jej urzeczywistnienia. W związku z tym nie dziwi fakt, że upatruje się w nich czynnika decydującego o kierunku rozwoju idei całożyciowego kształcenia.

\section{BibLIOGRAFIA}

Ciechanowska D., Od edukacji ustawicznej do całożyciowego uczenia się - potrzeba ksztatcenia kompetencji uczynienia się, [w:] R. Góralska, J. Półturzycki (red.), Edukacja ustawiczna w szkołach wyższych- od idei do praktyki, Płock-Toruń 2004.

Delores J. (red.), Edukacja - jest w niej ukryty skarb. Raport dla UNESCO Międzynarodowej Komisji do spraw Edukacji dla XXI wieku, Warszawa 1998.

Dubas E., Dorostość w erze informatycznej a zadania edukacji (dorostych), [w:] E. A. Wesołowska (red.), Edukacja dorostych werze globalizmu, Płock 2002.

Dzięgielewska M., Człowiek dorosły w społeczeństwie informatycznym, [w:] E. A. Wesołowska. (red.), Edukacja dorostych w erze globalizmu, Płock 2002.

Field J., Lifelong learning and the new educational order, Stock on Trent 2006.

Field J., Leicester M., Lifelong Learning. Education Across the Lifespan, Londyn 2000.

Frąckowiak A., Edukacja ustawiczna a szkoły wyższe w XXI wieku, [w:] R. Góralska, J. Półturzycki (red.), Edukacja ustawiczna w szkołach wyższych - od idei do praktyki, Płock-Toruń, 2004.

Góralska R., Półturzycki J. (red.), Edukacja ustawiczna w szkołach wyższych - od idei do praktyki, Płoc-Toruń, 2004.

Groenwald M., Edukacja przez całe życie - od idei do praktycznych rozwiazań, [w:] R. Góralska, J. Półturzycki (red.), Edukacja ustawiczna w szkołach wyższych - od idei do praktyki, Płock-Toruń 2004.

Illeris K., Trzy wymiary uczenia się, Wrocław 2006.

Karul J., Obszary pozaformalnej i nieformalnej edukacji dorostych. Przesłanki do budowania teorii edukacji całożyciowej, Wrocław 2001.

Kobylarek A., Uniwersytet - zarys ewolucji idei podstawowej, „Nauka i Szkolnictwo Wyższe” 2002, nr 1.

Kurantowicz E., O uczacych się społecznościach. Wybrane praktyki edukacyjne ludzi dorostych, Wrocław 2007.

Malewski M., Edukacja dorostych w pojęciowym zgiełku. Próba rekonstrukcji zmieniającej się racjonalności andragogiki, „Teraźniejszość - Człowiek - Edukacja" 2001.

Malewski M., Modele pracy edukacyjnej z ludźmi dorosłymi, „Teraźniejszość - Człowiek - Edukacja” 2000, nr 1 (9).

Półturzycki J., Szkolnictwo wyższe a idea edukacji ustawicznej, [w:] R. Góralska, J. Półturzycki (red.), Edukacja ustawiczna w szkołach wyższych-od idei do praktyki, Płock-Toruń 2004.

Scott P., The death of mass higher education and the birth of lifelong learning, [w:] J. Field, M. Leicester (red.), Lifelong Learning. Education Across the Lifespan, Londyn 2000.

Tuijnman A. C. (red.), International Encyklopedia of Adult Education and Training, Second Edition, London-New York-Tokyo, 1996.

Wesołowska E. A. (red.), Edukacja dorosłych w erze globalizmu, Płock 2002.

Wołk Z. (red.), Szkolnictwo wyższe w systemie kształcenia ustawicznego, Zielona Góra 2009.

Wołk Z., Wstęp, [w:] Z. Wołk (red.), Szkolnictwo wyższe w systemie kształcenia ustawicznego, Zielona Góra 2009. 


\section{NetOgRAFia}

Deklaracja Bolońska i co dalej: zbiór komunikatów, wytycznych i sugestii, materiały ze strony internetowej MENiS http://www. menis.gov.pl, Konferencja Rektorów Uniwersytetów Polskich, Poznań 2004.

Kędzierska B., Kształcenie ustawiczne jako priorytetowa koncepcja wszystkich krajów europejskich, http://www.wsp.krakow. pl/elemi/file/Kszt_Ust_podstawy.pdf, strona internetowa Uniwersytetu Pedagogicznego im. Komisji Edukacji Narodowej w Krakowie, 20.05.2010.

Korzan D., W poszukiwaniu istoty edukacji permanentnej, http://www.e-mentor.edu.pl/artykul_v2.php?numer=9\&id=146, wydanie internetowe czasopisma „E-mentor" 2005, nr 2, 10.05.2010.

Marciszewska E., Zbierzchowska A., Ksztatcenie ustawiczne na uniwersytetach. Projekty EQUIPE i EQUIPE PLUS, http:// www.e-mentor.edu.pl/artykul_v2.php?numer=16\&id=334, internetowe wydanie czasopisma „E-mentor" 2006, $\mathrm{nr}$ 4, 23.05.2010.

Mikołajczyk K., Ksztatcenie ustawiczne - od koncepcji do praktyki, www.cren.pl/CREN-SGH_15_KU_2007.pfd, 09.05.2010.

Półturzycki J., Aktualność problemów edukacji ustawicznej, http://www.e-mentor.edu.pl/artykul_v2.php?numer=13\&id=244 internetowe wydanie czasopisma „E-mentor” 2006, nr 1, 23.05.2010.

Półturzycki J., Źródła i tendencje rozwojowe edukacji ustawicznej, http://www.e-mentor.edu.pl/artykul_v2.php?nume$\mathrm{r}=7 \& \mathrm{id}=97$, wydanie internetowe czasopisma „E- mentor" 2004, nr 5, 10.05.2010.

Strona internetowa programu Grundtvig, http://grundtvig.org.pl/index.php/ida/2/, 23.05.2010.

Wiśniewski Z., Kształcenie ustawiczne - centralne czy niezależne?, http://www.e-mentor.edu.pl/artykul_v2.php?nume$\mathrm{r}=16 \& \mathrm{id}=337$, internetowe wydanie czasopisma „E- mentor" 2006, nr 4, 23.05.2010.

Wiśniewski Z., Rola uczelni w kształceniu ustawicznym w społeczeństwie na przykładzie potrzeb edukacyjnych osób powyżej 50 roku życia, http://www.e-mentor.edu.pl/artykul_v2.php?numer=26\&id=568, internetowe wydanie czasopisma „E- mentor" 2008, nr 4, 20.05.2010.

\section{Słowa kluczowe}

kształcenie ustawiczne, edukacja całożyciowa, uczelnie wyższe, uniwersytet, edukacja dorosłych.

\section{STRESZCZENIE}

Artykuł prezentuje stanowisko polskich uczelni wyższych wobec idei kształcenia ustawicznego. Dokonano porównania głównych teorii andragogicznych dotyczących badanego obszaru i ukazano ich ścisły związek z całożyciową edukacją ludzi dorosłych. Poddano analizie efektywność odmiennych stylów zarządzania kształceniem ustawicznym na uniwersytetach $\mathrm{i}$ ich konsekwencje dla działalności instytucji. Zarysowano również główne działania Komisji Europejskiej na rzecz upowszechniania kształcenia całożyciowego w Europie.

\section{INSTITUTIONS OF HIGHER EDUCATION AND THE IDEA OF LIFELONG LEARNING}

\section{Keywords}

lifelong learning, lifelong education, continuing education ,higher education, university, adult education

\section{Summary}

The idea of lifelong learning is very popular in the XXI century. This paper presents how Polish universities reflect this idea. The main theories of andragogy were compared with each other and a relationship was shown, between this concept and adult education. Moreover, it analyses the effectiveness of different management styles continuing education in Polish universities and their implications for institutions of higher education. It also describes the main programs of the European Commission to promote lifelong learning in Europe. 